\title{
DE OJOS Y MIRADAS
}

\author{
NOGUERA JJ ${ }^{1}$
}

De los ojos se han contado muchas cosas.

Para Cicerón, el rostro es el espejo del alma, y los ojos, sus delatores. De Alejandro Dumas es la afirmación de que Dios quiso que la mirada del hombre sea la única cosa que no se puede ocultar. Para el poeta y músico rondeño Vicente Espinel, los ojos son arcabuces y lumbreras del alma. El dramaturgo inglés John P. Fletcher dijo que la lengua del amor está en los ojos, y para William Shakespeare, el amor nace, vive y muere en los ojos.

Por su parte, los estudiosos de la fisiognomía determinaron que los ojos redondos corresponden a personas ingenuas y en las que se puede confiar; los ovalados son de joviales y sagaces, y los oblicuos, de las independientes y retraídas.

Los muy abiertos definen a quienes son confiados, sinceros y leales con los demás; los pequeños y redondos indican debilidad y candidez y, en general, son de personas desafortunadas y desprendidas.

Los ojos saltones son de extravagantes, malgastadores de su tiempo y su dinero, inconstantes en sus tareas y de buen corazón; mas ¡ay de los que los tienen hundidos y su mirada es inquietante y lejana!, pues son suspicaces, embusteros, celosos, coléricos, resabiados y también de malas costumbres.

Los ojos sin fuerza denotan codicia, envidia, holgazanería, indiscreción y torpeza intelectual. Quien mira con descaro y sus párpados siempre están abiertos es impío, carece de conciencia, y puede ser un impostor y aun cosas peores; los que guiñan los ojos y parpadean mucho son incrédulos, taimados y presuntuosos. Con frecuencia, los ojos estrábicos son de envidiosos, mentirosos, pendencieros, crueles, orgullosos, fanáticos e hipócritas.

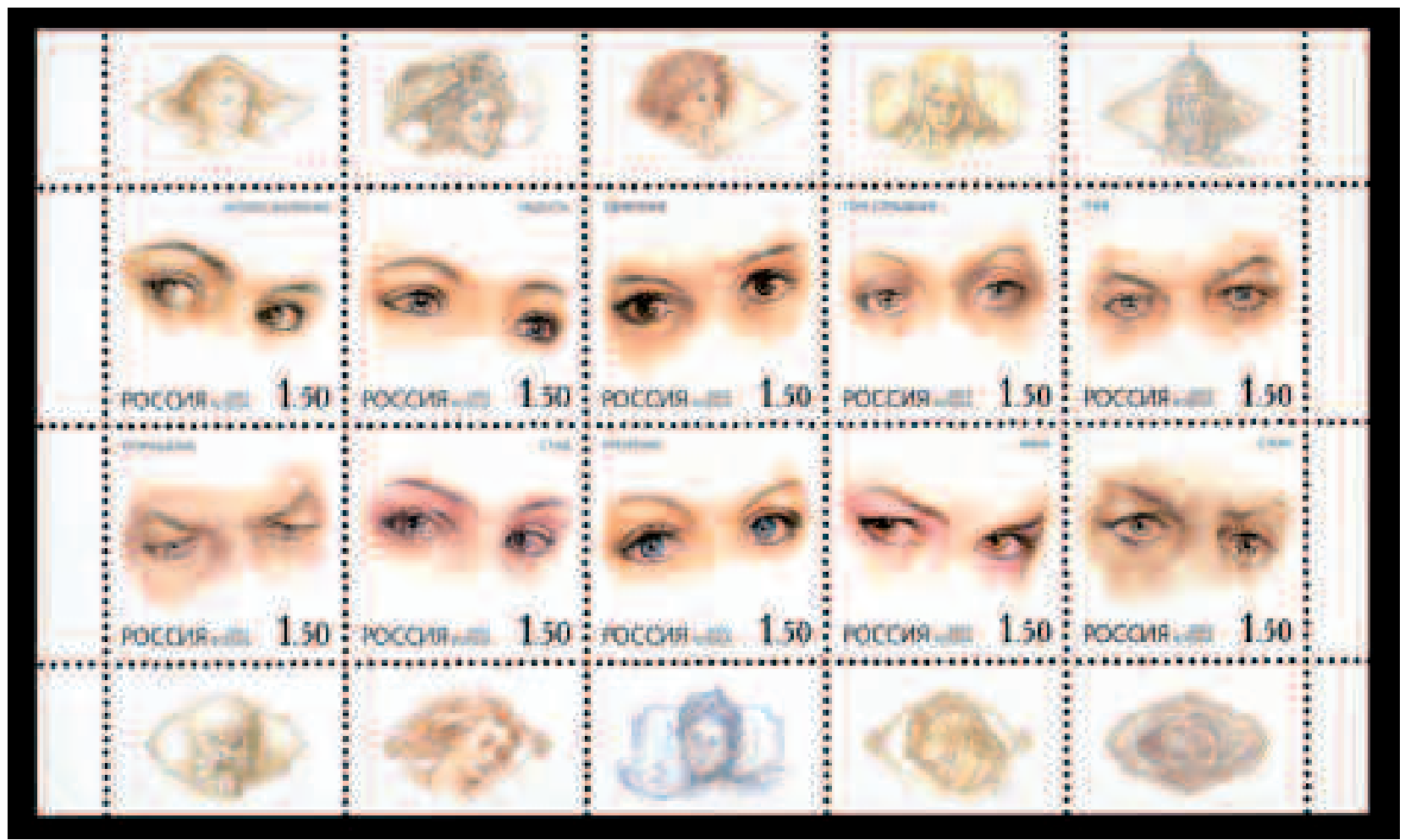

1 Oftalmólogo. Pamplona.

E-mail: jnoguera72b@terra.es 
Quienes tienen los ojos de buen tamaño, bien dispuestos, brillantes y con bellos párpados son de carácter fuerte, recto juicio y alma generosa; si los ojos son negros tienen una rica imaginación y más energía que los azules, más dados éstos al amor y a la paz...

Los correos rusos emitieron en 2002 diez sellos en una hojita (Yvert 6668/77) en los que se repre- sentan los ojos y las miradas de diferentes estados del alma, tanto en cada uno de los sellos como en la imagen correspondiente del borde. En la fila superior, de izquierda a derecha: emoción, alegría, asombro, sufrimiento y cólera; en la inferior: repugnancia, vergüenza, desprecio, culpa y miedo. 